Article

\title{
Source Apportionment of Nutrient Loads to a Mediterranean River and Potential Mitigation Measures
}

\author{
Anna Maria De Girolamo*(D) and Antonio Lo Porto \\ Water Research Institute, National Research Council, 70132 Bari, Italy; antonio.loporto@ba.irsa.cnr.it \\ * Correspondence: annamaria.degirolamo@ba.irsa.cnr.it; Tel.: +39-080-582-0547
}

Received: 9 January 2020; Accepted: 18 February 2020; Published: 20 February 2020

\begin{abstract}
The aims of the study were to quantify nutrient loads from point and diffuse pollution sources in the Rio Mannu stream and to simulate mitigation measures for reducing nutrient loads delivered to the Santa Gilla wetland. The Soil and Water Assessment Tool model was used for simulating hydrology, nutrient balance and water quality. At the basin scale, the input from fertilisers was $80.3 \mathrm{~kg} \mathrm{ha}^{-1}$ year $^{-1}$ total nitrogen (TN) (87.6\% of the total input) and $27.6 \mathrm{~kg} \mathrm{ha}^{-1} \mathrm{year}^{-1}$ of total phosphorus (TP) $(99.8 \%$ of the total input). Atmospheric deposition and biological $\mathrm{N}$-fixation together accounted for about $12 \%$ of the total TN input. The TN and TP from wastewater treatment plants (WWTPs) were about $14.2 \mathrm{t}$ year $^{-1}$ and $3.1 \mathrm{t} \mathrm{year}^{-1}$, respectively. Nutrient loads delivered to the river system differed among the sub-basins, with TP ranging from $0.2 \mathrm{~kg} \mathrm{ha}^{-1}$ year $^{-1}$ to $2.7 \mathrm{~kg} \mathrm{ha}^{-1}$ year $^{-1}$, and the sum of organic $\mathrm{N}$ and $\mathrm{NO}_{3}-\mathrm{N}$ ranging from $1.8 \mathrm{~kg} \mathrm{ha}^{-1}$ year ${ }^{-1}$ to $22.9 \mathrm{~kg} \mathrm{ha}^{-1} \mathrm{year}^{-1}$. Under high flow conditions, $\mathrm{NO}_{3}-\mathrm{N}$ and $\mathrm{TP}$ accounted for $89 \%$ and $99 \%$ of the total load, respectively. The low flow contribution to the total load was very low, with $\mathrm{NO}_{3}-\mathrm{N}$ and $\mathrm{TP}$ accounting for $2.8 \%$ and $0.7 \%$, respectively. However, the natural hydrological regime in the study area is intermittent, and low flow represents a critical condition for the water quality due to the high concentrations of TP and $\mathrm{NO}_{3}-\mathrm{N}$ from WWTP discharge. To improve the water quality, the reuse of treated wastewater from three WWTPs for irrigation purposes on olive cultivation, coupled with a $20 \%$ reduction in fertiliser application, was simulated. The results showed a reduction in nutrient loads at the outlet for all hydrological conditions. However, additional measures are needed for improving water quality.
\end{abstract}

Keywords: point and non-point source pollution; Mediterranean basin; temporary river; wastewater reuse; mitigation measures

\section{Introduction}

Water shortages and water quality are two relevant issues in many countries around the world. In the coming decades, water availability could be reduced as a result of climate change and economic development [1]. On the basis of our increased awareness of these problems, the Organisation for Economic Co-operation and Development Secretary-General has placed water at the centre of the global agenda, recognising that water availability and water quality constitute two of the most pressing global challenges [2].

With the Nitrate Directive [3] and Water Framework Directive (WFD) [4], the European member states have been called on to prevent the pollution of surface water and groundwater from point and diffuse sources. To achieve and maintain the good ecological status of surface waters, each state is expected to invest economic resources in a programme of measures. To do this, a preliminary analysis to quantify the anthropogenic pressures and their impacts on surface waters is necessary, and a detailed 
study is required for determining the source apportionment in order to prioritise the measures to be undertaken [5].

In recent decades, several approaches have been developed to quantify point and diffuse pollution [6]. Most of these methodologies require a large dataset, and the measurement of streamflow and concentrations of pollutants, which should be taken at a number of locations along the river network and should cover all hydrological conditions [7]. Whilst only measurements of streamflow and pollutant concentrations taken at the outlet can be used for estimating loads delivered to the sea on different time scales, these data are not sufficient for accurately apportioning point and diffuse pollution. Data availability is the major factor influencing the choice of methodological approach to be used for estimating non-point source pollution loads [8].

Export coefficient models (ECMs), which are widely used due to their ease of application, calculate nitrogen and phosphorus compounds delivered annually to a water body as the sum of the loads exported from each individual source present in the basin $[9,10]$. For each source, export coefficients can be derived from the literature, or can be estimated more accurately on the basis of the environmental characteristics of the study area (i.e. rainfall, slope, soil type), calibrated with field measurements [11]. Regression models use data recorded at a large number of gauging stations to estimate the source of nutrients [12]. Computational methodologies integrate the nutrient balance at the basin scale with ECMs [13].

Conceptual models, such as the Soil and Water Assessment Tool (SWAT) [14], Annualized Agricultural Non-Point Source (AnnAGNPS) [15] or GREEN-Rgrid [16], are generally complex, their use requiring a large amount of data and a specific knowledge of the processes acting in the study area [17]. These models provide more detailed results, at different time and spatial scales, and offer the possibility of simulating the impacts of climate change [18], land-use change and of best management practices (BMPs) [19]. In addition, conceptual models are able to quantify the impact of point sources on surface waters.

Point source discharge can constitute an important and relevant pressure on the river ecosystem, especially in intermittent streams where the dilution effect is limited [20]. Although its relevance has been recognised, few studies have focused on the impact of point sources on intermittent streams [21]. Research is needed to identify and test measures for mitigating the impacts of point sources on river ecosystems.

In the present study, the SWAT model was applied to the Rio Mannu basin, an area that experiences water shortages and water pollution, the river network having an intermittent character. This work is a continuation of previous studies aimed at quantifying diffuse pollution from the area's current crop production and for land-use change [22,23], and also quantifying the grey water footprint for durum wheat production [24]. The results highlight that some measures are needed to improve surface-water quality.

The first objective of this work was to quantify the nutrient loads from point and diffuse pollution to the Rio Mannu stream, the second to simulate some mitigation measures for reducing the nutrient loads being delivered to the wetland. In particular, the use of treated wastewater from urban wastewater treatment plants (WWTPs) for the irrigation of cultivated olive trees and a reduction in fertiliser usage rates were tested. The results of this study will be useful for water resources managers, in terms of both the methodological aspects and the relevance of the results, especially for basins with intermittent river systems.

\section{Study Area}

The Rio Mannu basin (southern Sardinia, Italy) covers an area of $488 \mathrm{~km}^{2}$ (Figure 1). The Rio Mannu stream (locally known as the Rio Mannu di San Sperate) is a tributary of the Flumini Mannu River that drains into a coastal brackish pond (Santa Gilla), a wetland site protected under the Ramsar Convention that hosts a variety of Mediterranean floral and bird species. The elevation ranges from 70 to $960 \mathrm{~m}$ a.s.l. The climate is typically Mediterranean, featuring very high temperatures that often 
exceed $40^{\circ} \mathrm{C}$ during the summer. The average annual precipitation in the basin was about $500 \mathrm{~mm}$ from 1996 to 2006. The wet season is from October to March. Rainfall events are short, but intense, especially in summer, and are generally unevenly distributed. The rainfall regime characteristics influence the flow regime and, consequently, its sediment and nutrient delivery. The flow regime experiences a dry season from May to September, with an extremely low flow, or an absence of surface flow, interrupted by a few flash floods, and a wet season, during which the hydrograph changes rapidly. The major soil types are Typic, Dystrict, Lithic Xerorthents (clay-loam, deep), vertic Xerochrepts (sandy-loam, sandy-clay-loam, deep) and Lithic Xerorthents (sandy-loam, loamy-clay, shallow). Following the US Natural Resources Conservation Service soil classification [25], the major soil series in the basin fall within hydrological groups $C$ and $D$, the drainage properties of which range from moderate to low.

Agriculture is the main economic activity in the basin, with durum wheat $(37 \%)$, olive trees $(8 \%)$, alsike clover $(5 \%)$ and vineyards $(2.24 \%)$ being the main crops cultivated, while minor land use includes alfalfa $(1.5 \%)$, corn silage $(0.5 \%)$ and orchards $(1.56 \%)$. Natural forest $(4 \%)$ and range grasses $(28 \%)$ are present along the borders of the basin. The basin experiences water scarcity, and the sources of water pollution include runoff from cropland and urban areas and effluent from the WWTPs.
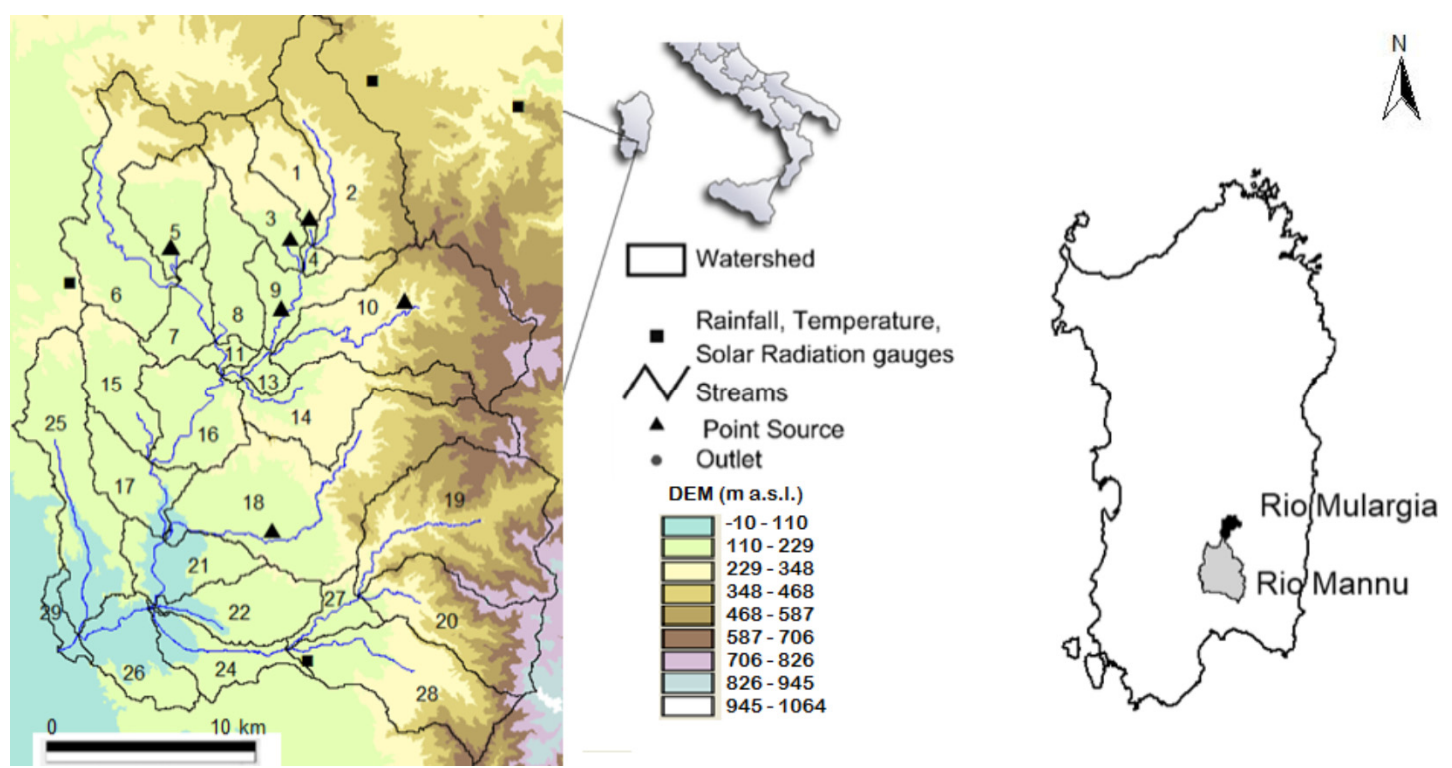

Figure 1. Study area.

\section{Materials and Methods}

To protect and improve water quality and ecosystem state, mitigation measures have to be defined and implemented as response to anthropogenic pressures for reducing nutrient input to the aquatic system. The definition of a programme of measures requires the analysis of the gap between the water's current status and the "good status". In the present paper, a methodological approach was developed to: (i) quantify point and non-point source pollution in a catchment with intermittent river systems and identify critical source areas, (ii) assess water quality, and (iii) evaluate mitigation measures. Figure 2 shows the schematic overview of the method.

In the first step of the methodological approach, point and non-point source pollution were quantified in the Rio Mannu basin by using the SWAT model, a hydrological and water quality model. A preliminary study and a survey of the basin was carried out for building the conceptual model of the river basin. After the model calibration, the nutrient concentrations and nutrient load apportionment were used to identifying the critical source areas where the mitigation measures should be implemented.

In the second step, the divergence between the water's current status and the water quality standards was assessed. For intermittent streams, an analysis of the nutrient concentrations for the 
different flow conditions (high, normal, and low flow) was proposed. This analysis may provide a solid basis to evaluate the programme of measures in watersheds with intermittent streams characterised by a high variability in streamflow and nutrient concentration $[8,26]$. Indeed, high nutrient concentrations during floods (high flow) are mainly due to agriculture as delivered to the stream with surface runoff, meanwhile the high concentrations of pollutants in low flow condition are mainly attributable to point sources.

In the last step, a scenario analysis was developed by using the SWAT model in order to evaluate mitigation measures. The efficiency of the designed measures in terms of nutrient load reduction was assessed through a comparison of the model results with the current condition (baseline). All the steps of the methodological approach are described in details below.

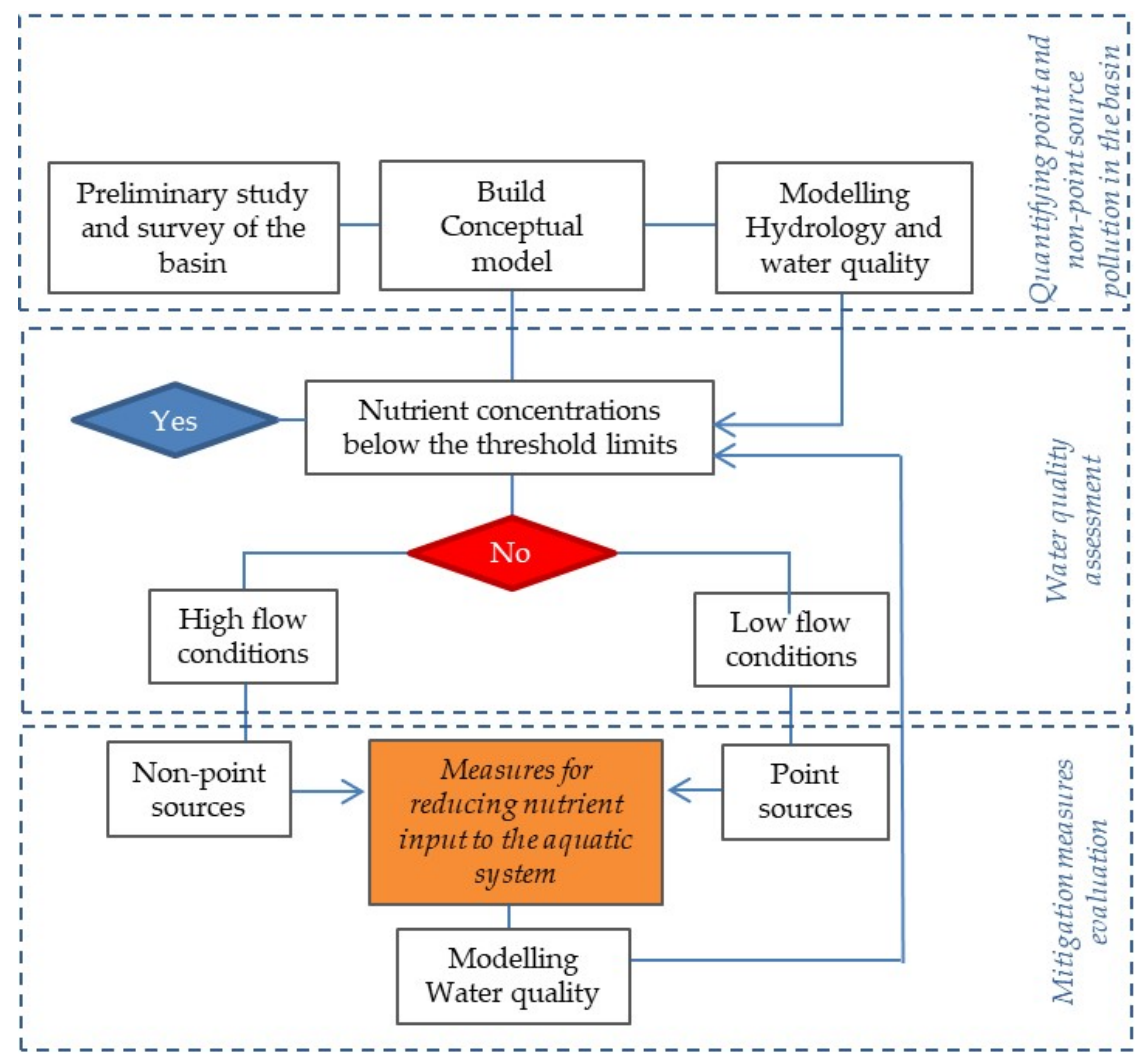

Figure 2. Schematic overview of the method.

\subsection{Quantifying Point and Non-Point Source Pollution}

The SWAT model was developed to predict the impact of land management practices on water, sediments and agricultural chemical yields in ungauged river basins [14]. The model is widely used in hydrological $[8,26]$ and water-quality analyses at the basin scale $[27,28]$ to assess the impact of land-use changes or climate changes on surface waters $[19,29]$.

The model was run on a daily time-step from January 1994 to May 2007, with three years of warm up. A spatial subdivision into 29 subbasins and 185 hydrological response units (HRUs) was defined in order to include the most complete climatic, soil and land-use data available. The Hargreaves method was used to evaluate the evapotranspiration, and the Soil Conservation Service (SCS) Curve Number method was selected to calculate surface runoff. An SCS Curve Number was assigned to each HRU, taking into consideration soil type, land use and slope, according to the US Department of Agriculture method [30].

Further details about the model setup for the study area, the input data, anthropogenic pressures (fertilisers and WWTPs) and model calibration results have been reported in De Girolamo et al. [22-24]. 
In their works, the authors used a regionalisation scheme based on parameter transposition from the adjacent Rio Mulargia gauged catchment [31]. Indeed, according to Bárdossy [32], for basins with similar characteristics, it is possible to transfer parameters from the donor basin if the model performances are good. In particular, upon comparing the topography, soils and aquifer at a shallow depth between the study area and the Rio Mulargia basin, the curve numbers and groundwater parameters were able to be adjusted. An estimation of channel roughness, through a direct survey of the river network, was conducted in order to determine the Manning coefficients. The adopted parameters have been reported by De Girolamo and Lo Porto [23].

The water-quality calibration (total nitrogen [TP] and total phosphorus [TN]) was performed at the outlet of the Rio Mannu from 2006 to 2007, when discrete measurements of the nutrients were taken (two per month). In this period, rainfall was about 16\% higher than the average computed from 1994 to 2007. The default values for the cover factor (Universal Soil Loss Equation), nitrogen percolation coefficient, residue decomposition coefficient and biological mixing efficiency were modified to match the simulated and observed monthly concentrations [23]. No further validation process was possible due to the limited availability of measured data. Crop yield was compared with official data at the province [33] and farm levels, the data being collected from farmer interviews.

Inputs of TN and TP from point and non-point sources were computed at the basin scale, and the model results were analysed in order to estimate the nutrient input to the aquatic system at different spatial and temporal scales. The simulation of the current environmental conditions, which included point and non-point source pollution, was named through the paper baseline. The source apportionment of the point and non-point sources at the basin scale was performed by comparing the baseline with a new simulation that excluded the point sources.

\subsection{Water Quality Assessment}

Water quality status was assessed at the outlet of the basin comparing $\mathrm{TP}$ and $\mathrm{NO}_{3}-\mathrm{N}$ concentrations simulated by the calibrated model at daily time scale with the threshold limits that are required to support a functioning ecosystem, $0.1 \mathrm{mg} \mathrm{L}^{-1}$ and $1.2 \mathrm{mg} \mathrm{L}^{-1}$, respectively (Level II, Italian Decree 260/2010 [34]). For linking the flow regime and water quality, TP and $\mathrm{NO}_{3}-\mathrm{N}$ concentrations were reported in the flow duration curve (FDC) plot, which shows the percentage of time during which a specified flow is equaled or exceeded.

\subsection{Evaluating Mitigation Measures for Reducing Nutrient Input to the Aquatic System}

In the context of the WFD, mitigation measures are defined as the practicable operations that may be taken to mitigate the adverse impacts of anthropogenic activities. Optimal use of fertilizers, agricultural practices that reduce erosion, buffer zones, and artificial wetlands are among the central measures to mitigate the impact of agriculture. On the other hand, improvement in wastewater treatment efficiency for nutrients is necessary especially for those countries where this is a serious issue [35]. Hence, a quantification of the sources of nutrients (i.e., agriculture, industry, atmospheric deposition, sewage) is required before identifying the mitigation options, as well as it is necessary to show in which way mitigation options could influence processes and patterns. At this aim, a conceptual framework was proposed.

The calibrated model was used to examine the effects of changes in management practices on nutrient loads delivered to the wetland. In particular, a reduction in fertiliser amount applied to the main crops and the reuse of treated wastewater from the WWTPs were simulated and compared with the baseline.

Several studies have reported that treated wastewater can be used for the irrigation of olive groves $[36,37]$ because, from the agronomic point of view, no significant differences have been found between products irrigated with tap water and those irrigated with treated wastewater.

In the present study, the reuse of treated wastewater from WWTPs for irrigation was tested in three sub-basins (labelled as 3, 9 and 18 in Figure 1), including only the largest plants (with treated 
volumes of $>300 \mathrm{~m}^{3} \mathrm{~d}^{-1}$ ). Wastewater from small WWTPs and from plants $>5 \mathrm{~km}$ from the irrigation districts was not included in this scenario because the benefits, in terms of saving water, would be very low compared to the costs of the plants (i.e. irrigation network, pumping station). An irrigation season for olive production was considered, from April to October, using a volume of about 2700-3100 $\mathrm{m}^{3} \mathrm{ha}^{-1}$. A wastewater reservoir can be used to provide storage capacity to cope with changes in water demand for irrigation during the year. Such reservoirs play a significant role in the removal of heavy metals, detergents and toxic organics. A TN and TP removal rate of $60 \%$ was considered, as suggested by Juanicó and Milstein [38] and Guyer [39], based on a retention time of about 60 days. In order to calculate nutrient loads input to the soil from wastewater, effluent data from the WWTPs were considered, such as daily discharge and composition, in terms of nutrients, which were fixed at the maximum permissible limits of $15 \mathrm{mg} \mathrm{L}^{-1}$ and $2 \mathrm{mg} \mathrm{L}^{-1}$ for TN and TP, respectively [40]. A reduction in fertiliser amount of about $17 \mathrm{~kg} \mathrm{ha}^{-1} \mathrm{TN}$ and about $2 \mathrm{~kg} \mathrm{ha}^{-1} \mathrm{TP}$ in early spring was introduced in this option for the olive cultivations in the selected subbasins. Table 1 summarises the daily volumes of effluent from the WWTPs and the irrigated areas, and the corresponding nutrient loads made to the soil from wastewater.

The calculation and distribution of an optimal fertiliser application would require detailed measurements and nutrient management planning, which may cost more than would be saved in fertiliser costs; for this reason, farmers often over-apply nitrogen. A monoculture of cereals and the loss of soil productivity due to erosion have contributed to an over-application of fertilisers in the study area. For this reason, the reuse of wastewater for irrigation purposes was coupled to a $20 \%$ reduction in fertiliser application rate on corn, durum wheat, alfalfa, grape vines, olive trees, winter pasture and alsike clover production, in order to simulate the impact on surface waters and to quantify any potential improvement in water quality. To achieve this aim, the simulation kept all the input variables constant (weather, soil, land use, management practices), except for the fertiliser applications and the WWTP discharge, which varied according to the policy scenario.

Table 1. Volumes of effluent from WWTPs and irrigated areas, and volumes of irrigation water and nutrient loads $(\mathrm{TN}, \mathrm{TP})$ made to the soil from wastewater.

\begin{tabular}{|c|c|c|c|c|c|}
\hline Sub-Basin & $\begin{array}{c}\text { Volume of } \\
\text { Effluent }\left(\mathrm{m}^{3} \mathrm{~d}^{-1}\right)\end{array}$ & ha & $\begin{array}{l}\text { Volume of Irrigation } \\
\left(\mathrm{m}^{3} \mathrm{ha}^{-1} \text { year }^{-1}\right)\end{array}$ & $\begin{array}{c}\text { TN } \\
\left(\mathrm{kg} \mathrm{ha}^{-1} \text { year }^{-1}\right)\end{array}$ & $\begin{array}{c}\text { TP } \\
\left(\mathrm{kg} \mathrm{ha}^{-1} \text { year }^{-1}\right)\end{array}$ \\
\hline 3 & 300 & 35 & 3129 & 17 & 2.2 \\
\hline 9 & 1430 & 186 & 2806 & 18 & 2.5 \\
\hline 18 & 1091 & 145 & 2709 & 16 & 2.2 \\
\hline
\end{tabular}

\section{Results}

\subsection{Modelling Point and Non-Point Sources}

The results of the hydrological calibration were considered satisfactory, as reported by De Girolamo and Lo Porto [23], because the simulated monthly flow fell within the interval of its natural variability, as defined by \pm 1 standard deviation ( $\mathrm{SD}_{\mathrm{obs}}$ ) from the mean of the measured monthly streamflow from 1922 to 1967 [41], which were the only available data (Table 2). In their work, De Girolamo and Lo Porto [23] pointed out that, in recent decades, changes in the rainfall regime had been recorded, with a reduction in the amount of rainfall in winter and an increase in late summer. Consequently, modifications occurred in the hydrological regime, with a reduction in streamflow in winter and an increase in autumn [23]. 
Table 2. Historical monthly runoff $\left(\mathrm{Q}_{\mathrm{obs}}\right)$ measured from 1922 to 1964 at the outlet, and relative standard deviation $\left(\mathrm{SD}_{\mathrm{obs}}\right)$ and simulated monthly runoff from 1997 to $2006\left(\mathrm{Q}_{\mathrm{sim}}\right)$.

\begin{tabular}{|c|c|c|c|c|c|c|c|c|c|c|c|c|}
\hline $\begin{array}{l}\text { Monthly } \\
\text { Runoff }\end{array}$ & January & February & March & April & May & June & July & August & September & October & November & December \\
\hline $\mathrm{Q}_{\mathrm{obs}}(\mathrm{mm})$ & 3.4 & 3.4 & 3.3 & 1.5 & 0.8 & 0.4 & 0.2 & 0.1 & 0.3 & 0.6 & 1.3 & 3.7 \\
\hline $\mathrm{SD}_{\mathrm{obs}}$ & 2.9 & 3.4 & 3.2 & 2.3 & 0.9 & 0.6 & 0.2 & 0.2 & 0.7 & 2.4 & 2.2 & 4.2 \\
\hline
\end{tabular}

For water quality, the Nash-Sutcliffe efficiency (NSE) and percent bias (PBIAS) were used to evaluate the model's efficiency. The performance of the model was considered satisfactory, with the PBIAS being $12.68 \%$ and $-3.32 \%$ for TP and TN, respectively, while the NSE was 0.52 for TP and 0.76 for TN [42]. Table 3 shows the measured and simulated TN and TP.

Table 3. Observed and simulated TN and TP concentration at the Monastir River section.

\begin{tabular}{|c|c|c|c|c|c|c|c|c|c|c|c|}
\hline $\begin{array}{c}\text { Conc. } \\
\left(\mathrm{mg} \mathrm{L}^{-1}\right)\end{array}$ & $\begin{array}{c}12 \\
\text { December }\end{array}$ & $\begin{array}{c}27 \\
\text { December }\end{array}$ & $\begin{array}{c}17 \\
\text { January }\end{array}$ & $\begin{array}{c}31 \\
\text { January }\end{array}$ & $\begin{array}{c}12 \\
\text { February }\end{array}$ & $\begin{array}{c}27 \\
\text { February }\end{array}$ & $\begin{array}{c}3 \\
\text { March }\end{array}$ & $\begin{array}{c}17 \\
\text { March }\end{array}$ & $\begin{array}{c}5 \\
\text { April }\end{array}$ & $\begin{array}{c}27 \\
\text { April }\end{array}$ & $\begin{array}{c}15 \\
\text { May }\end{array}$ \\
\hline TN obs & 4.89 & 4.18 & 4.99 & 6.19 & 4.41 & 4.69 & 3.49 & 4.40 & 2.34 & 3.63 & 4.02 \\
\hline TN sim & 2.67 & 1.73 & 4.37 & 5.54 & 1.51 & 1.17 & 3.87 & 5.75 & 1.19 & 6.40 & 5.59 \\
\hline TP obs & 0.23 & 0.12 & 0.25 & 0.25 & 0.28 & 0.29 & 0.18 & 0.31 & 0.18 & 0.3 & 0.51 \\
\hline TP sim & 0.15 & 0.08 & 0.46 & 0.21 & 0.07 & 0.06 & 0.33 & 0.66 & 0.05 & 0.51 & 0.41 \\
\hline
\end{tabular}

\subsection{Estimating Nutrient Loads from the Point and Non-Point Sources}

At the basin scale, a nutrient balance was calculated that included the inputs of TN and TP from point and non-point sources. The TN and TP inputs, as sums of the point and non-point sources, were about $4470 \mathrm{t} \mathrm{year}^{-1}$ and $1350 \mathrm{t}_{\text {year }}{ }^{-1}$, respectively (Table 4).

Table 4. Inputs of TN and TP in the Rio Mannu basin from point and non-point sources as average annual values from 1997 to 2006.

\begin{tabular}{|c|c|c|c|c|c|}
\hline \multicolumn{4}{|c|}{ Non-Point Sources } & \multicolumn{2}{|c|}{ Point Sources (WWTPs) } \\
\hline & (kg year-1) & $\left(\mathrm{kg} \mathrm{ha}^{-1}\right.$ year $\left.^{-1}\right)$ & & $\left(\mathrm{m}^{3}\right.$ year $\left.^{-1}\right)$ & $\left(\mathrm{kg} \mathrm{year}^{-1}\right)$ \\
\hline TN fertiliser applied & $3,918,640$ & 80.3 & $\mathrm{TN}$ & & 14,180 \\
\hline TP fertiliser applied & $1,346,880$ & 27.6 & $\mathrm{TP}$ & & 3143 \\
\hline TN fixation & 283,040 & 5.8 & Discharge & $1,347,945$ & \\
\hline $\mathrm{TN}$ in rain & 253,760 & 5.2 & & & \\
\hline
\end{tabular}

Inputs from fertilisers were $80.3 \mathrm{~kg} \mathrm{ha}^{-1} \mathrm{year}^{-1} \mathrm{TN}$ ( $88 \%$ of the total TN input) and $27.6 \mathrm{~kg} \mathrm{ha}^{-1}$ year $^{-1}$ TP $(99.7 \%$ of the total TP input). Atmospheric deposition and biological TN fixation together accounted for about $12 \%$ of the total TN input. The TN and TP from the WWTPs were about $14.2 \mathrm{t}_{\text {year }}{ }^{-1}$ and $3.1 \mathrm{t}_{\text {year }}{ }^{-1}$, respectively. The average annual organic $\mathrm{N}$ and $\mathrm{NO}_{3}-\mathrm{N}$ input to the aquatic system simulated by the model at the basin scale over the study period was $10.27 \mathrm{~kg} \mathrm{ha}^{-1}$ year ${ }^{-1}$ and $4.42 \mathrm{~kg} \mathrm{ha}^{-1}$ year $^{-1}$, respectively (Table 5). An interannual variability was simulated that depended on the weather conditions. These results are in good agreement with the values estimated by Leip et al. [43]. Over the study period, the average annual load of TP adducted to the river system was $1.28 \mathrm{~kg} \mathrm{ha}^{-1}$ year $^{-1}$. At the outlet, the mean daily loads of TP, TN and NO3-N were estimated to be about $313 \mathrm{~kg} \mathrm{~d}^{-1}\left(114 \mathrm{t}_{\text {year }}{ }^{-1}\right), 1799 \mathrm{~kg} \mathrm{~d}^{-1}\left(657 \mathrm{t} \mathrm{year}^{-1}\right)$ and $909 \mathrm{~kg} \mathrm{~d}^{-1}\left(332 \mathrm{t} \mathrm{year}^{-1}\right)$, respectively. The results are in the range estimated by Malagò et al. [16] from 2003 to 2007 (TP estimated range from $0 \mathrm{t}$ year ${ }^{-1}$ to $250 \mathrm{t}$ year ${ }^{-1}$; TN estimated range from $0 \mathrm{t} \mathrm{year}^{-1}$ to $2000 \mathrm{t} \mathrm{year}^{-1}$ ).

In order to differentiate the nutrient load contributions from the point and non-point sources, a new model simulation was performed that excluded WWTPs. As expected, the results showed a slight reduction in nutrient load (from $2 \%$ to $5 \%$ ) because of the exclusion of the WWTPs; these were $306 \mathrm{~kg} \mathrm{~d}^{-1}, 1745 \mathrm{~kg} \mathrm{~d}^{-1}$ and $868 \mathrm{~kg} \mathrm{~d}^{-1}$ for TP, $\mathrm{TN}$ and $\mathrm{NO}_{3}-\mathrm{N}$, respectively. 
Table 5. Loads input to the river system (TP, organic $\mathrm{N}, \mathrm{NO}_{3}-\mathrm{N}$ ), $\mathrm{NO}_{3}-\mathrm{N}$ percolation, and crop uptake (TP, TN) simulated by the SWAT model at the basin scale for the current conditions from 1997 to 2006.

\begin{tabular}{|c|c|c|c|c|c|c|}
\hline \multirow{3}{*}{$\begin{array}{l}\text { Annual Specific } \\
\text { Load }\end{array}$} & Surf. Water & Surf. Water & Surf. Water & Percolation & Crop Uptake & Crop Uptake \\
\hline & TP & Organic $\mathbf{N}$ & $\mathrm{NO}_{3}-\mathrm{N}$ & $\mathrm{NO}_{3}-\mathrm{N}$ & TP & $\mathrm{TN}$ \\
\hline & $\mathrm{kg} \mathrm{ha}^{-1}$ year $^{-1}$ & $\mathrm{~kg} \mathrm{ha}^{-1}$ year $^{-1}$ & $\mathrm{~kg} \mathrm{ha}^{-1}$ year $^{-1}$ & $\mathrm{~kg} \mathrm{ha}^{-1}$ year $^{-1}$ & $\mathrm{~kg} \mathrm{ha}^{-1}$ year $^{-1}$ & $\mathrm{~kg} \mathrm{ha}^{-1}$ year $^{-1}$ \\
\hline Average & 1.28 & 10.27 & 4.42 & 2.91 & 7.63 & 51.2 \\
\hline SD & 0.76 & 6.11 & 0.88 & 0.96 & 1.48 & 9.95 \\
\hline
\end{tabular}

The nutrient load delivered to the river system differed from one sub-basin to another, in terms of both TP and TN. As Figure 3 shows, the TP ranged from $0.2 \mathrm{~kg} \mathrm{ha}^{-1} \mathrm{year}^{-1}$ to $2.7 \mathrm{~kg} \mathrm{ha}^{-1} \mathrm{year}^{-1}$, and the sum of organic $\mathrm{N}$ and $\mathrm{NO}_{3}-\mathrm{N}$ ranged from $1.8 \mathrm{~kg} \mathrm{ha}^{-1}$ year ${ }^{-1}$ to $22.9 \mathrm{~kg} \mathrm{ha}^{-1}$ year ${ }^{-1}$. The results at the sub-basin scale identified the areas contributing most of the TN and TP in the basin, where a programme of measures is needed. In the sub-basins with the highest nutrient loads, the main crops were alsike clover, alfalfa, durum wheat, corn silage and olives, whereas natural areas hosting range brush and range grasses were the predominant land uses in those sub-basins with the lowest specific loads of TN and TP.
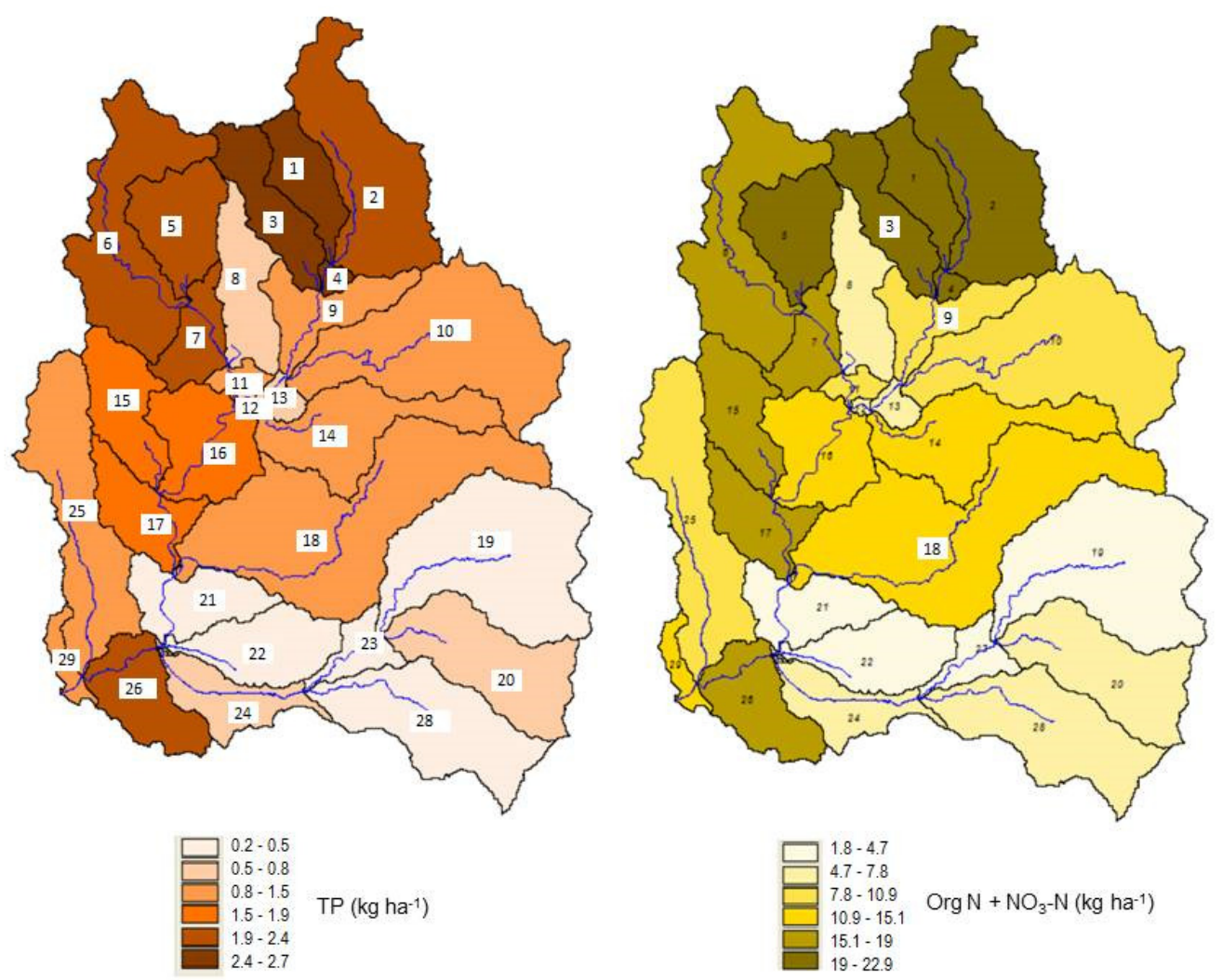

Figure 3. Average annual load of TP $\left(\mathrm{kg} \mathrm{ha}^{-1}\right.$ year $\left.^{-1}\right)$ and organic $\mathrm{N}+\mathrm{NO}_{3}-\mathrm{N}\left(\mathrm{kg} \mathrm{ha}^{-1}\right.$ year $\left.{ }^{-1}\right)$, simulated at the sub-basin scale.

\subsection{Estimating Riverine Nutrient Concentrations at the Outlet}

The FDC, the $\mathrm{NO}_{3}-\mathrm{N}$ concentrations and their corresponding threshold limit of $1.2 \mathrm{mg} \mathrm{L}^{-1}$, and the TP concentrations and their corresponding threshold limit of $0.1 \mathrm{mg} \mathrm{L}^{-1}$ [34] were analysed for both the baseline and for the scenario with no point sources (Figure 4).

In the baseline scenario, both the $\mathrm{NO}_{3}-\mathrm{N}$ and TP concentrations were generally higher than the above-mentioned corresponding threshold limits. During floods, a high amount of nutrients was exported from the agricultural lands and delivered to the river through surface runoff. In high flow regimes (exceedance frequency $0-20 \% ; \mathrm{Q}>0.497 \mathrm{~m}^{3} \mathrm{~s}^{-1}$ ), the concentration decreases in accordance 
with the flow. In contrast, under normal flow conditions (exceedance frequency $20-50 \% ; 0.497 \mathrm{~m}^{3} \mathrm{~s}^{-1}$ $>\mathrm{Q}>0.114 \mathrm{~m}^{3} \mathrm{~s}^{-1}$ ), the average $\mathrm{NO}_{3}-\mathrm{N}$ concentration assumed a wide range of values, while the TP concentration increased with a decrease in flow. Under low flow conditions, both $\mathrm{NO}_{3}-\mathrm{N}$ and TP concentrations increased with a decrease in flow; this behaviour is due to a reduction in the dilution effect of effluent coming from the WWTPs.

Concerning the nutrient loads, it was found that, under high flows, $\mathrm{NO}_{3}-\mathrm{N}$ and TP accounted for $89 \%$ and $99 \%$ of the total load, respectively. In the baseline scenario, the low flow contribution to the total load was very low, with $\mathrm{NO}_{3}-\mathrm{N}$ and TP accounting for $2.8 \%$ and $0.7 \%$ of the total load, respectively.

Although, in terms of nutrient loads, the normal and low flow conditions were not noteworthy, these hydrological phases represent critical conditions for water quality due to the high concentrations of TP and $\mathrm{NO}_{3}-\mathrm{N}$ they carry. The river system is intermittent under natural conditions. As Figure 4 shows, in the absence of effluent coming from the WWTPs, the river is dry for about two months per year, and the FDC assumes a different pattern compared to the baseline. Figure 3 refers to the yearly average climatic conditions, with $454 \mathrm{~mm}$ of annual rainfall, recorded in 2000.
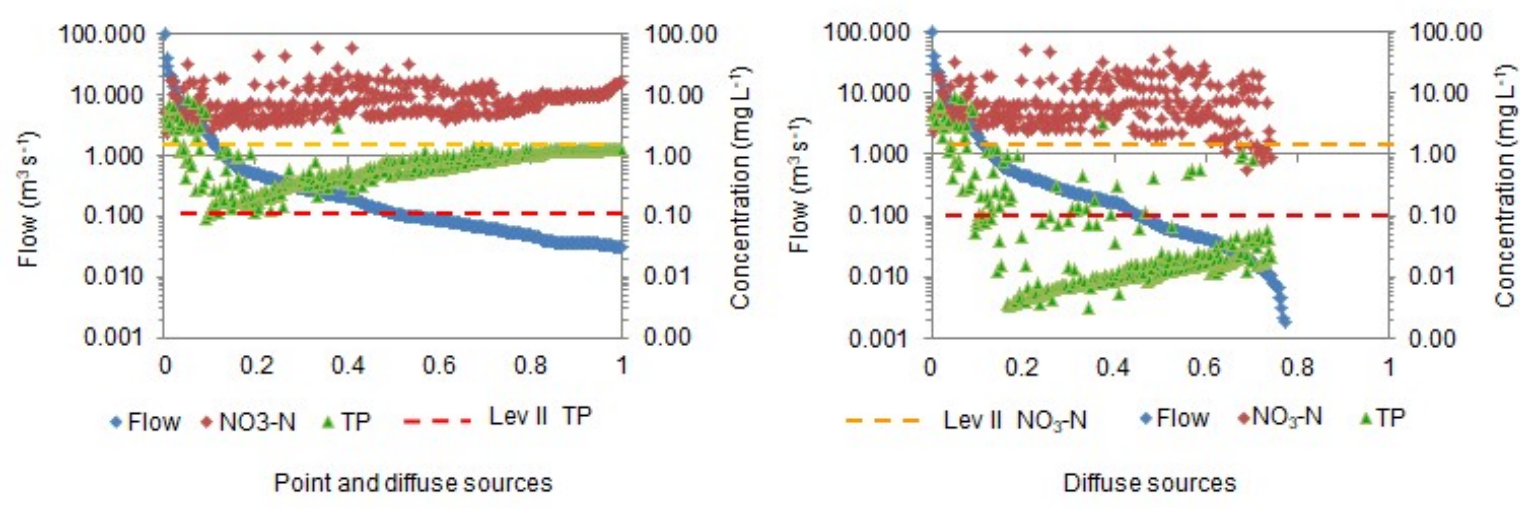

Figure 4. Flow duration curve and daily concentrations of $\mathrm{NO}_{3}-\mathrm{N}$ and $\mathrm{TP}$ for baseline (left) and for non-WWTP discharge into the river (right).

A large difference between the two conditions (with and without WWTPs) was found in the TP concentration pattern. Indeed, in the absence of point sources, the TP concentrations were generally lower than those recorded in the baseline scenario, both for normal and low flow conditions (Figure 3). The TP concentrations were higher than Level II of Italian Decree 260/2010 [34] predominantly under high flow conditions (exceedance frequency $0-20 \%$ ), whilst, under normal and low flows, they were generally below than that limit. Differences in the $\mathrm{NO}_{3}-\mathrm{N}$ concentration patterns were also found between the baseline and the scenario with no point sources. In general, in the absence of point sources, under high flows, the concentrations were similar to those of the baseline, while in low flow conditions, the $\mathrm{NO}_{3}-\mathrm{N}$ concentrations were lower than those recorded in the baseline scenario, and their values decreased with decreasing flow (Figure 4). Hence, it can be deduced that the contribution of the point sources to surface water pollution relates to low flow conditions, while non-point source pollution is mainly responsible for high concentrations and loads under high and normal flow conditions.

Based on this analysis, it seems evident that, the nutrient loads from point sources may be critical, especially for those river reaches that are naturally intermittent. For those river segments, there is no dilution effect in summer and, for this reason, in-stream nutrient concentrations exceed desirable values [34], although the nutrient concentrations in treated wastewater effluent do adhere to the water-quality threshold limits.

\subsection{Evaluation of a Scenario for Reducing Nutrient Input to the Aquatic System-the Reuse of Treated Wastewater from WWTPs and a Reduction in Fertiliser Usage}

The results of the scenario aimed at reducing nutrient input to the aquatic system to improve water quality, which included the reuse of treated wastewater for irrigation purposes on olive cultivations 
coupled with a reduction in the amount of fertiliser applied to the main crops, were analysed. At the outlet, the SWAT model simulated a reduction in nutrient loads under all hydrological conditions (high, normal, low flows) (Figure 5). Under high flow conditions, the reduction was $9 \%$ and $12 \%$ for $\mathrm{NO}_{3}-\mathrm{N}$ and TP, respectively. The reduction increased under normal and low flow conditions $(75 \%$ and $83 \%$ for $\mathrm{NO}_{3}-\mathrm{N}$ and $\mathrm{TP}$, respectively).

As Figure 5 shows, although the reduction, in terms of the load, was considerable, the TP and $\mathrm{NO}_{3}-\mathrm{N}$ concentrations in the surface water were higher than the Level-II threshold limits (indicated by dashed lines). It can thus deduce that the wastewater discharged into the river by small WWTPs (not included in the reuse scenario) had a significant impact on surface water quality under normal and low flows.
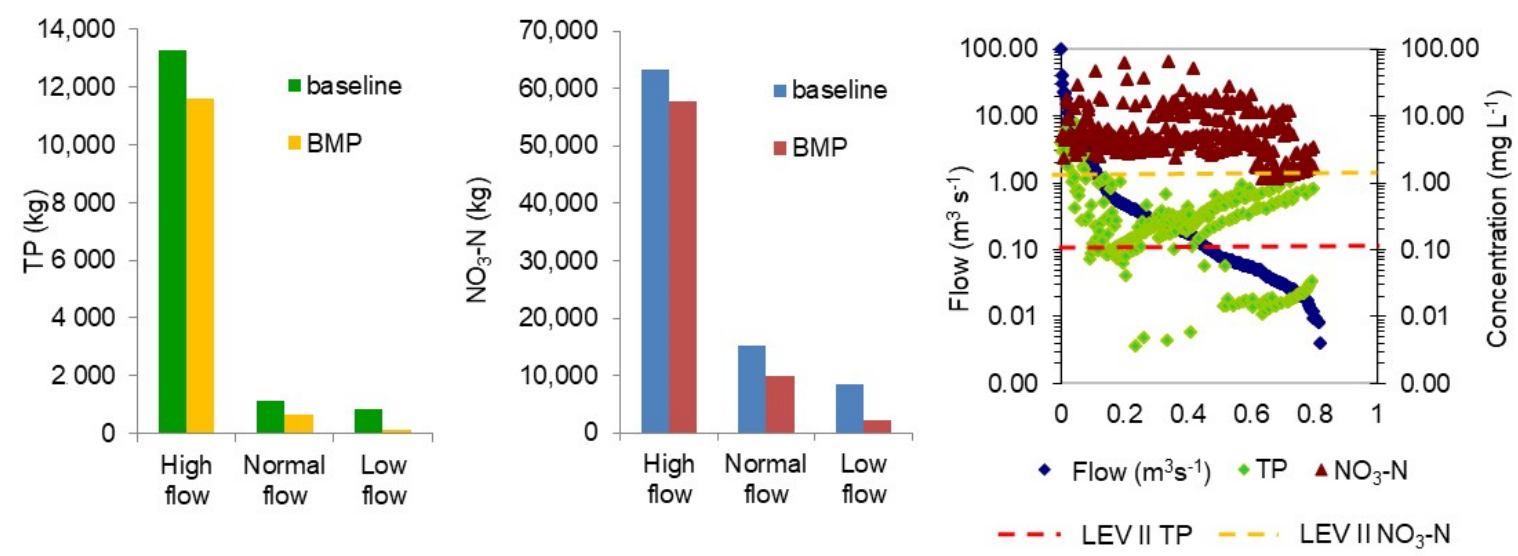

Figure 5. TP and $\mathrm{NO}_{3}-\mathrm{N}$ loads simulated at the outlet under current conditions (baseline) and for a scenario (BMP) that included the reuse of treated wastewater from WWTPs and a reduction in fertiliser usage. The flow duration curve, $\mathrm{TP}$ and $\mathrm{NO}_{3}-\mathrm{N}$ concentrations for the BMP scenario are shown.

\section{Discussion}

With the WFD, adopted in 2000 by the EU, all member states are expected to pursue the goal of protecting and restoring their aquatic ecosystems. The general objective of the WFD was the achievement of a good status for all EU waters by 2015. Due to watercourse degradation and ineffective management, perpetrated over several decades, a good ecological status was not achieved by 2015 in about half of the EU's surface waters [44,45]. The ambitious goal of the WFD required complex river basin management and, in the implementation process, some management plans have been directed towards the symptoms rather than the causes of the water degradation [44,45]. Consequently, there is still a long way to go, and the EU member states still have much work to do to achieve a good ecological status for all their waters and, generally, to improve their river basin management programmes.

In the present work, some mitigation measures were explored that could reduce the nutrient loads delivered to the wetland after estimating the current water quality and nutrient source apportionment. To quantify the point and diffuse pollution, modelling activities, coupled with a few monitoring data, were used. Although, in recent years, many efforts have been made to increase environmental monitoring and make the data more easily accessible, several small river basins with intermittent river networks, such as the study area, are still poorly monitored $[8,46]$. Here, hydrologists and ecologists are expected to find new approaches to overcome the difficulties that derive from data paucity. In the present work, the SWAT model was applied, and transposition of the relevant hydrological parameters from an adjacent basin was adopted to overcome the absence of streamflow data in the immediate study area [32]. The uncertainty associated with the modelling results, in this case, could be large, but despite its limitations, the model proved to be a valuable tool for estimating the hydrology and point and diffuse pollution, and for simulating the scenarios. 
In the Rio Mannu basin, the results of the present study indicated that agriculture is the main source of $\mathrm{NO}_{3}-\mathrm{N}$ in the surface waters. This is not surprising, as it is well known that fertilisers are the main diffuse source of nitrate contamination in agricultural basins [47]. The point sources made a minor contribution, in terms of nutrient load to the surface waters, but they constitute a relevant hydrological pressure for the Rio Mannu, producing a shift from an intermittent hydrological regime (natural conditions) towards a perennial regime. These hydrological shifts have several implications for the water quality, especially in the dry season because of the limited dilution effect, and on the river morphology, habitats and biota, through the establishment of non-native species, and consequently on the ecological status of the stream [48]. The results of the present study show that, in the absence of WWTP discharges into the river, TP concentrations would remain higher than the threshold limit under high flow conditions (73 days), while the TP would generally be lower than the limit for most of the year. Concerning $\mathrm{NO}_{3}-\mathrm{N}$, it seems that the contribution of the WWTPs is irrelevant, under both high and normal flow conditions, while a slight reduction in nitrate concentrations may occur under low flow conditions in the absence of discharge from WWTPs.

Point sources may be a critical issue for several intermittent streams, especially in those countries where the regulation limits for nutrient concentrations in WWTP effluent are higher than the water-quality target concentrations of the receiving water body. This study highlights the relevance of the water-quality aspects related to WWTP discharges, demonstrating that specific measures are needed to improve water quality, both under high and low flow conditions. Indeed, as climate change proceeds, it is expected that the dry season will be extended and there will be a shift towards more frequent intermittent flow conditions; presumably, this problem will affect a larger number of streams.

In view of these results, a reduction in fertiliser usage on the main crops and the reuse of treated wastewater from WWTPs were simulated as potential measures for reducing nutrient loads and concentrations. In a circular economy, wastewater should no longer be considered as waste, but as a new resource [49-51]. Although several barriers to this exist in basins experiencing water shortage, such as the Rio Mannu, such as public perception [52], the level of contaminants [53], especially the emerging pollutants, and economic aspects, the use of treated wastewater for irrigation may represent a new source of water for agriculture. At the same time, such reuse realises two additional goals: first, a decrease in the pressure on surface waters receiving waste, and second a reduction in fertiliser application rates on cultivations irrigated with the treated wastewater that is a source of nutrients [49]. Petousi et al. [37] pointed out that the irrigation of olive trees with treated wastewater in arid and semi-arid regions could be an alternative to addressing issues of water shortages. The authors monitored soil and plants during and after 3-years of irrigation with treated wastewater, concluding that secondary and tertiary treated wastewater can be used for the safe irrigation of olive groves. Erel et al. [36] highlighted the likelihood of adverse effects associated with long-term irrigation using reclaimed wastewater related to the deterioration of soil physical and chemical properties. Further studies are needed to analyse the impacts on soil.

After testing scenarios that included a $20 \%$ reduction in the amount of fertiliser used and wastewater reuse, the results showed a reduction in the nutrient load delivered to the wetland. However, these measures alone are not sufficient to reach a good water-quality status because the concentrations of $\mathrm{NO}_{3}-\mathrm{N}$ and TP remain high. Consequently, supplementary measures should be implemented, such as precision farming and organic production. In addition, further improvements in water quality under normal and low flow conditions could be obtained by adopting a more efficient system for those WWTPs with locations (too far from irrigation districts or with critical slopes between the WWTP and irrigable land) or sizes that do not lend themselves to the reuse of treated wastewater. Indeed, a reduction in nutrients, emerging pollutants and metals could be achieved by adopting more advanced WWTPs or alternatives such as phytoremediation systems [54]. Mitigation measures to reduce the nutrient loads delivered to the surface waters are urgent because nutrient loadings were found particularly sensitive to climate change [55], especially considering that it is expected for the future an extension of the dry season and an exacerbation of the extreme low flow conditions [18]. 
Implementation of the measures tested in the present study would require investment from both the public and private sectors. A reduction in fertiliser usage would bring a diminution in crop yields, while measures such as precision farming or organic production would need an initial investment for their implementation. The adoption of BMPs by farmers is generally strictly related to economic incentives. However, it is also necessary to remove the social and political barriers that limit the adoption of such measures. Indeed, a lack of awareness of the causes and effects of agricultural practices induces most farmers not to relate BMPs to the indirect benefits. Therefore, actions are also needed to increase awareness among farmers of the environmental impacts of agriculture, and to remove the barriers that limit the adoption of BMPs. Some indirect interventions, such as providing information and technical assistance, could be strengthened to help inform and support those farmers who are willing, but unable, to change their agricultural systems towards adopting BMPs.

\section{Conclusions}

In this study, the SWAT model—a hydrological and water-quality tool—was applied to estimate the nutrient loads delivered downstream to Santa Gilla wetland and to analyse nutrient load apportionment within the Rio Mannu basin. In addition, specific measures for reducing nutrient loads and improving water quality were simulated. Despite its limitations, the model proved to be a valuable tool for estimating nutrient riverine export and for testing scenarios for reducing nutrient loads, as required by the WFD. Further monitoring activities and an improved dataset could improve the nutrient balance calculations and nutrient concentration estimations.

The results of the present study show that agriculture is the main source of the nutrients in the surface waters. Most of the nutrient loads are delivered to the wetland under high flow conditions. In addition, it was found that point source discharge constitutes a relevant issue for intermittent streams, even if the nutrient loads discharged into the streams are not considerable. Currently, the threshold limits for nutrients in effluent discharged into streams are fixed for perennial streams, and do not take into consideration that the dilution effect is absent, or very limited, in intermittent streams under normal and low flow conditions. As a result, downstream of WWTP discharges, nutrient concentrations in surface waters are higher than those allowed by water-quality standards. On the other hand, WWTP discharge alters the natural hydrological regime of those streams that become perennial. The shift from an intermittent to a perennial regime may have several implications for river morphology and biota.

Based on this study, it is evident that a programme of measures for improving the current status of surface waters must be oriented towards reducing nutrient loads, both under high and low flow conditions. The results here show that a $20 \%$ reduction in fertiliser usage on the main crops in this area, and the reuse of wastewater from a few selected WWTPs, would result in a significant reduction in the nutrient load delivered to the wetland, although this reduction is not large enough, and supplementary measures would be required. Actions are needed to increase the awareness among farmers of the environmental impacts of agriculture, and to remove barriers that limit the adoption of BMPs. Further studies are needed to estimate the economic feasibility of such measures, for both the public and private sectors.

Author Contributions: Conceptualization, A.M.D.G.; methodology, A.L.P. and A.M.D.G.; software, A.M.D.G.; validation, A.M.D.G.; formal analysis, A.L.P. and A.M.D.G.; investigation, A.L.P. and A.M.D.G.; data curation, A.M.D.G.; writing A.M.D.G.; review and editing, A.M.D.G. and A.L.P.; visualization, A.M.D.G.; supervision, A.M.D.G.; project administration, A.L.P.; funding acquisition, A.L.P. All authors have read and agreed to the published version of the manuscript.

Funding: The study was partially developed within the EU FP6 Aquastress Project (Contr. no. 511231-2).

Acknowledgments: The authors gratefully acknowledge Domenico Usai for sharing his knowledge, and Massimo Aiello and Stefania Zaccolo for collecting the agronomic data and organising the meetings with the farmers and stakeholders.

Conflicts of Interest: The authors declare no conflict of interest. 


\section{References}

1. United Nations World Water Assessment Programme. UN-Water. The United Nations World Water Development Report 2018: Nature-Based Solutions for Water; United Nations Educational, Scientific and Cultural Organization: Paris, France, 2018; Available online: http://unesdoc.unesco.org/images/0026/002614/261424e.pdf (accessed on 19 February 2020).

2. Gurría, A. (OECD Secretary-General). In OECD: Putting Water at the Centre of the Global Agenda; OECD: Paris, France, 2017; pp. 1-6. Available online: https://www.oecd.org/water/SG-Water-lecture-April-2017.pdf (accessed on 19 February 2020).

3. European Commission. Directive 91/676/EEC Concerning the Protection of Waters against Pollution Caused by Nitrates from Agricultural Sources (Nitrates Directive); OJ (1991) L375/1; European Commission: Brussels, Belgium, 1991.

4. European Commission. Directive 2000/60/EC of the European Parliament and the Council Establishing a Framework for Community Action in the Field of Water Policy (Water Framework Directive); OJ L 327 of 22.12.2000; European Commission: Brussels, Belgium, 2000.

5. Malagó, A.; Bouraoui, F.; Pastori, M.; Gelati, E. Modelling Nitrate Reduction Strategies from Diffuse Sources in the Po River Basin. Water 2019, 11, 1030. [CrossRef]

6. Zhang, Y.; Collins, A.L.; Murdoch, N.; Lee, D.; Naden, P.S. Cross sector contributions to river pollution in England and Wales: Updating waterbody scale information to support policy delivery for the Water Framework Directive. Environ. Sci. Policy 2014, 42, 16-32. [CrossRef]

7. De Girolamo, A.M.; Di Pillo, R.; Lo Porto, A.; Todisco, M.; Barca, E. Identifying a reliable method for estimating suspended sediment load in a temporary river system. Catena 2018, 165, 442-453. [CrossRef]

8. D'Ambrosio, E.; De Girolamo, A.M.; Spanò, M.; Corbelli, V.; Capasso, G.; Morea, M.; Velardo, R.; Abdelwahab, O.M.M.; Lonigro, A.; Milillo, F.; et al. A spatial analysis to define data requirements for hydrological and water quality models in data-limited regions. Water 2019, 11, 267. [CrossRef]

9. Ding, X.; Shen, Z.; Hong, Q.; Zhifeng, Y.; Wu, X.; Liu, R. Development and test of the Export Coefficient Model in the Upper Reach of the Yangtze River. J. Hydrol. 2010, 383, 233-244. [CrossRef]

10. Johnes, P.J. Evaluation and management of the impact of land use change on the nitrogen and phosphorus load delivered to surface waters: The export coefficient modelling approach. J. Hydrol. 1996, 183, 323-349. [CrossRef]

11. Franke, N.A.; Boyacioglu, H.; Hoekstra, A.Y. Grey Water Footprint Accounting: Tier 1 Supporting Guidelines; Unesco-IHE: Delft, The Netherland, 2013.

12. Alexander, R.B.; Elliott, A.H.; Shankar, U.; Mcbride, G.B. Estimating the source and transport of nutrients in the Waikato River Basin, New Zealand. Water Resour. Res. 2002, 38, 1268-1290. [CrossRef]

13. De Girolamo, A.M.; Spanò, M.; D’Ambrosio, E.; Ricci, G.F.; Gentile, F. Developing a nitrogen load apportionment tool: Theory and application. Agric. Water Manag. 2019, 226, 105806. [CrossRef]

14. Arnold, J.G.; Srinivasan, R.; Muttiah, R.S.; Williams, J.R. Large area hydrologic modeling and assessment-Part 1: Model development. J. Am. Water Resour. Assoc. 1998, 34, 73-89. [CrossRef]

15. Theurer, F.D.; Cronshey, R.G. AnnAGNPS-Reach Routing Processes. In Proceedings of the First Federal Interagency Hydrologic Modeling Conference, Las Vegas, NV, USA, 19-23 April 1998.

16. Malagó, A.; Bouraoui, F.; Grizzetti, B.; De Roo, A. Modelling nutrient fluxes into the Mediterranean Sea. J. Hydrol. Reg. Stud. 2019, 22, 100592. [CrossRef]

17. Abdelwahab, O.M.M.; Ricci, G.F.; De Girolamo, A.M.; Gentile, F. Modelling soil erosion in a Mediterranean watershed: Comparison between SWAT and AnnAGNPS models. Environ. Res. 2018, 166, 363-376. [CrossRef]

18. De Girolamo, A.M.; Bouroui, F.; Buffagni, A.; Pappagallo, G.; Lo Porto, A. Hydrology under climate change in a temporary river system: Potential impact on water balance and flow regime. River Res. Appl. 2017, 33, 1219-1232. [CrossRef]

19. Glavan, M.; Bele, S.; Pintar, M. Modelling Impacts of Municipal Spatial Plan land-use changes on surface water quality-Example from Goriška Brda in Slovenia. Water 2020, 189. [CrossRef]

20. D'Ambrosio, E.; Gentile, F.; De Girolamo, A.M. Assessing the sustainability in water use at the basin scale through water footprint indicators. J. Clean. Prod. 2020, 244, 118847. [CrossRef] 
21. Tournoud, M.-G.; Perrin, J.-L.; Gimbert, F.; Picot, B. Spatial evolution of nitrogen and phosphorus loads along a small Mediterranean river: Implication of bed sediments. Hydrol. Process. 2005, 19, 3581-3592. [CrossRef]

22. De Girolamo, A.M.; Lo Porto, A.; Oueslati, O. Modeling nutrient balances in the Rio Mannu basin and scenario analysis of the impact of fertilizer reduction. Fresenius Environ. Bull. 2010, 19, 1854-1861.

23. De Girolamo, A.M.; Lo Porto, A. Land use scenario development as a tool for watershed management within the Rio Mannu Basin. Land Use Policy 2012, 29, 691-701. [CrossRef]

24. De Girolamo, A.M.; Miscioscia, P.; Politi, T.; Barca, E. Improving grey water footprint assessment: Accounting for uncertainty. Ecol. Indic. 2019, 102, 822-833. [CrossRef]

25. USDA Natural Resources Conservation Service. Soil Water Characteristics. Available online: https://www. nrcs.usda.gov/wps/portal/nrcs/detailfull/national/water/manage/drainage/?cid=stelprdb1045310 (accessed on 30 June 2017).

26. De Girolamo, A.M.; Barca, E.; Pappagallo, G.; Lo Porto, A. Simulating ecologically relevant hydrological indicators in a temporary river system. Agric. Water Manag. 2017, 180, 194-204. [CrossRef]

27. Ricci, G.F.; De Girolamo, A.M.; Abdelwahab, O.M.; Gentile, F. Identifying sediment source areas in a Mediterranean watershed using the SWAT model. Land Degrad. Dev. 2018, 29, 1233-1248. [CrossRef]

28. Pulighe, G.; Bonati, G.; Colangeli, M.; Traverso, L.; Lupia, F.; Altobelli, F.; Dalla Marta, A.; Napoli, M. Predicting streamflow and nutrient loadings in a semiarid Mediterranean watershed with ephemeral streams using the SWAT model. Agronomy 2019, 10, 2. [CrossRef]

29. Čerkasova, N.; Umgiesser, G.; Ertürk, A. Assessing Climate Change Impacts on Streamflow, Sediment and Nutrient Loadings of the Minija River (Lithuania): A Hillslope Watershed Discretization Application with High-Resolution Spatial Inputs. Water 2019, 11, 676. [CrossRef]

30. United States Department of Agriculture-Soil Conservation Service, National Engineering Handbook; Section 4; Hydrology USDA-SCS: Washington, DC, USA, 1985.

31. De Girolamo, A.M.; De Luca, F.; Lo Porto, A.; Botti, P.; Canè, G.; Diliberto, L. Studio dell'inquinamento da fonti diffuse nel bacino del Rio Mulargia-Applicazione del modello SWAT. L'Acqua 2008, 1, 73-80.

32. Bárdossy, A. Calibration of hydrological model parameters for ungauged catchments. Hydrol. Earth Syst. Sci. 2007, 11, 703-710. [CrossRef]

33. ISTAT. Annual Crop Data. Italian National Institute of Statistics. 2008. Available online: http://agri.istat.it (accessed on 3 September 2018).

34. Ministero dell'Ambiente e della Tutela del Territorio e del Mare. D.M. 08 Novembre 2010, n. 260. G.U. n. 30 del 7/02/2011, Suppl. Ordinario n. 31; Istituto Poligrafico e Zecca dello Stato S.p.A.: Roma, Italy, 2010.

35. Thieu, V.; Garnier, J.; Billen, G. Assessing the effect of nutrient mitigation measures in the watersheds of the Southern Bight of the North Sea. Sci. Total Environ. 2010, 408, 1245-1255. [CrossRef]

36. Erel, R.; Eppel, A.; Yermiyahu, U.; Ben-Gal, A.; Levy, G.; Zipori, I.; Schaumann, G.E.; Mayer, O.; Dag, A. Long-term irrigation with reclaimed wastewater: Implications on nutrient management, soil chemistry and olive (Olea europaea L.) performance. Agric. Water Manag. 2019, 213, 324-335. [CrossRef]

37. Petousi, I.; Fountoulakis, M.S.; Saru, M.L.; Nikolaidis, N.; Fletcher, L.; Stentiford, E.I.; Manios, T. Effects of reclaimed wastewater irrigation on olive (Olea europaea L. cv. 'Koroneiki') trees. Agric. Water Manag. 2015, 160, 33-40. [CrossRef]

38. Juanicó, M.; Milstein, A. Semi-intensive treatment plants for wastewater reuse in irrigation. Water Sci. Technol. 2004, 50, 55-60. [CrossRef]

39. Guyer, J.P. An Introduction to Nutrient Removal in Wastewater Treatment Ponds; The Clubhouse Press: El Macero, CA, USA, 2018.

40. Presidente della Repubblica. D. Lgs. 3 aprile 2006, n. 152. G.U. n.88 del 14/4/2006, Suppl. Ordinario n. 96; Istituto Poligrafico e Zecca dello Stato S.p.A.: Roma, Italy, 2006.

41. Richter, B.D.; Baumgartner, J.V.; Powell, J.; Braun, D.P. A method for assessing hydrologic alteration within ecosystems. Conserv. Biol. 1996, 10, 1163-1174. [CrossRef]

42. Moriasi, D.N.; Arnold, J.G.; Van Liew, M.W.; Bingner, R.L.; Harmel, R.D.; Veith, T.L. Model Evaluation Guidelines for Systematic Quantification of Accuracy in Watershed Simulations. Trans. ASAE 2007, 50, 885-900. [CrossRef]

43. Leip, A.; Britz, W.; Weiss, F.; de Vries, W. Farm, land, and soil nitrogen budgets for agriculture in Europe calculated with CAPRI. Environ. Pollut. 2011, 159, 3243-3253. [CrossRef] [PubMed] 
44. European Environment Agency. Report No 7/2018. European Waters Assessment Status and Pressures; European Environment Agency: Copenhagen, Denmark, 2018. [CrossRef]

45. Voulvoulis, N.; Arpon, K.D.; Giakoumis, T. The EU Water Framework Directive: From great expectations toproblems with implementation. Sci. Total Environ. 2017, 575, 358-366. [CrossRef] [PubMed]

46. De Girolamo, A.M.; Balestrini, R.; D’Ambrosio, E.; Pappagallo, G.; Soana, E.; Lo Porto, A. Antropogenic input of nitrogen and riverine export from a Mediterranean catchment. The Celone, a temporary river case study. Agric. Water Manag. 2017, 187, 190-199. [CrossRef]

47. Bouraoui, F.; Grizzetti, B. Long term change of nutrient concentrations of rivers discharging in European seas. Sci. Total Environ. 2011, 409, 4899-4916. [CrossRef] [PubMed]

48. De Girolamo, A.M.; Lo Porto, A.; Pappagallo, G.; Tzoraki, O.; Gallart, F. The Hydrological Status Concept: Application at a Temporary River (Candelaro, Italy). River Res. Appl. 2015, 31, 892-903. [CrossRef]

49. Voulvoulis, N. Water reuse from a circular economy perspective and potential risks from an unregulated approach. Curr. Opin. Environ. Sci. Health 2018, 2, 32-45. [CrossRef]

50. Vergine, P.; Lonigro, A.; Salerno, C.; Rubino, P.; Berardi, G.; Pollice, A. Nutrient recovery and crop yield enhancement in irrigation with reclaimed wastewater: A case study. Urban Water J. 2017, 14, 325-330. [CrossRef]

51. Ait-Mouheb, N.; Bahri, A.; Thayer, B.B.; Benyahia, B.; Bourrié, G.; Cherki, B.; Condom, N.; Declercq, R.; Gunes, A.; Héran, M.; et al. The reuse of reclaimed water for irrigation around the Mediterranean Rim: A step towards a more virtuous cycle? Reg. Environ. Chang. 2018, 18, 693-705. [CrossRef]

52. Michetti, M.; Raggi, M.; Guerra, E.; Viaggi, D. Interpreting Farmers' Perceptions of Risks and Benefits Concerning Wastewater Reuse for Irrigation: A Case Study in Emilia-Romagna (Italy). Water 2019, 11, 108. [CrossRef]

53. Ravindran, V.B.; Soni, S.K.; Ball, A.S. A Review on the Current Knowledge and Prospects for the Development of Improved Detection Methods for Soil-Transmitted Helminth Ova for the Safe Reuse of Wastewater and Mitigation of Public Health Risks. Water 2019, 11, 1212. [CrossRef]

54. Riggio, V.A.; Ruffino, B.; Campo, G.; Comino, E.; Comoglio, C.; Zanetti, M. Constructed wetlands for the reuse of industrial wastewater: A case-study. J. Clean. Prod. 2018, 171, 723-732. [CrossRef]

55. Sperotto, A.; Molina, J.L.; Torresan, S.; Critto, A.; Pulido-Velazquez, M.; Marcomini, A. Water Quality Sustainability Evaluation under Uncertainty: A Multi-Scenario Analysis Based on Bayesian Networks. Sustainability 2019, 11, 4764. [CrossRef]

(C) 2020 by the authors. Licensee MDPI, Basel, Switzerland. This article is an open access article distributed under the terms and conditions of the Creative Commons Attribution (CC BY) license (http://creativecommons.org/licenses/by/4.0/). 